Abstracta Iranica Abstracta Iranica

Revue bibliographique pour le domaine irano-aryen

Volume 22 | 2001

Comptes rendus des publications de 1999

\title{
«Manuscrits persans de la Bibliothèque nationale de France se rapportant à l'Asie centrale ». Cahiers d'Asie Centrale, 7, (1999), pp. 57-63.
}

\section{Rédaction}

\section{(2) OpenEdition}

\section{Journals}

Édition électronique

URL : http://journals.openedition.org/abstractairanica/35973

DOI : 10.4000/abstractairanica.35973

ISSN : 1961-960X

Éditeur :

CNRS (UMR 7528 Mondes iraniens et indiens), Éditions de l'IFRI

\section{Édition imprimée}

Date de publication : 15 mai 2001

ISSN : 0240-8910

\section{Référence électronique}

Rédaction, « "Manuscrits persans de la Bibliothèque nationale de France se rapportant à l'Asie centrale ». Cahiers d'Asie Centrale, 7, (1999), pp. 57-63. », Abstracta Iranica [En ligne], Volume 22 | 2001, document 8, mis en ligne le 15 février 2010, consulté le 10 octobre 2020. URL : http:// journals.openedition.org/abstractairanica/35973; DOI : https://doi.org/10.4000/abstractairanica 35973

Ce document a été généré automatiquement le 10 octobre 2020

Tous droits réservés 


\section{«Manuscrits persans de la} Bibliothèque nationale de France se rapportant à l'Asie centrale ». Cahiers d'Asie Centrale, 7, (1999), pp. 57-63.

\section{Rédaction}

1 Étude présentant les ms. persans copiés en Asie centrale ou ayant figuré dans des collections d'Asie centrale de la BnF. Sont mentionnés les différentes spécificités de ces livres dont il est donné la liste, ainsi que l'origine (collection de Decourdemanche, d'Ollone et d'Edouard Blanc surtout). Les ms. anciens sont rares et la plus grande production représentée est celle du $19^{\mathrm{e}} \mathrm{s}$. Ces ms. présentent en outre des spécificités qui appelleront des études plus précises.

\section{INDEX}

Thèmes : 1.1. Bibliographie

\section{AUTEURS}

\section{RÉDACTION}

Directeur de la revue et secrétariats (Paris et Téhéran) 